\title{
VARIATION IN HEAVY METAL CONTENT IN PLANTS GROWING ON A ZINC AND LEAD TAILINGS DUMP
}

\author{
SzWALEC, A. - LASOTA, A. - KęDZior, R. - MundatA, P.* \\ Department of Ecology, Climatology and Air Protection, University of Agriculture in Krakow \\ 24/28 Mickiewicz Av., 30-059 Krakow, Poland \\ *Corresponding author \\ e-mail:rmmundal@cyf-kr.edu.pl \\ (Received $14^{\text {th }}$ May 2018; accepted $11^{\text {th }}$ Jul 2018)
}

\begin{abstract}
Industrial waste landfills might cause contamination of agricultural land, forests, surface water and groundwater through migration of toxic substances, including heavy metals, posing a threat to all living organisms, including humans. The aim of the study was to assess the variation in $\mathrm{Cd}, \mathrm{Pb}$, $\mathrm{Zn}$ and $\mathrm{Cu}$ content in plants growing on a zinc and lead post-flotation tailings dump. The concentrations of the elements in the shoots and leaves of silver birch, black locust, common rowan, herbaceous plants and soil were determined by the flame atomic adsorption spectrophotometry (FAAS) method. The statistical nalysis indicates a significant relationship between the $\mathrm{Pb}$ and $\mathrm{Zn}$ concentrations and the plant species, plant part, and location on the dump. Differences in cadmium concentrations depending on the plant species were also statistically significant. None of these relationships was significant in the case of copper content. The mean biological concentration factors (BCF) were higher in plants growing on the southern slope of the dump. Of the elements analysed, zinc and cadmium were accumulated in larger quantities than lead and copper.
\end{abstract}

Keywords: post-flotation tailings, heavy metals, bioindicators different plant species, ore mining residues

\section{Introduction}

Human activity is associated with the generation of waste. Its quantity increases every year as a result of continuous technological progress and the development of civilization. It should be noted that new technologies used for extraction and processing of raw materials increase the diversity of generated waste (Salihoglu, 2010; Janas and Zawadzka, 2017; Koolivand et al., 2017). By-products of human activity generated during extraction and industrial processing of raw materials are known as industrial waste. The composition and quantity of industrial waste are linked to the type of production and the specific industry. An important consideration is the environmental harm and nuisance caused by this waste. According to Eurostat data, the total amount of waste from mining and extraction activity in the EU in 2014 was 700.8 billion $\mathrm{kg}$. At the end of that year, 2,123.9 billion $\mathrm{kg}$ of mineral waste remained deposited in landfills (Eurostat, 2017). In Poland, 31.2 billion $\mathrm{kg}$ of waste was generated in flotation enrichment of non-ferrous ores in 2016. At the end of that year, 635.4 billion $\mathrm{kg}$ of this type of waste remained deposited on landfills, of which 38.4 million Mg was in sites located in Małopolska (PCSO, 2017). Industrial and postindustrial sites are found all over the world, and more attention and research should be devoted to them due to the threat they pose to the environment (Grattan et al., 2003; Pyatt et al., 2000, 2005; Stefanowicz et al., 2014; Teršič et al., 2009; Alloway, 2013). Industrial waste landfills could cause contamination of agricultural land, forests, surface water and groundwater through the migration of toxic substances, including heavy metals, thereby posing a threat to all living organisms, including humans 
(Tordoff et al., 2000; Wong, 2003; Klojzy-Kaczmarczyk et al., 2005). Heavy metals can persist in high concentrations for decades or even millennia. Their transport to agricultural soils, sediments and watercourses occurs gradually and is associated with high levels of pollution of the natural environment. None of the technologies currently in use completely protects the environment from the negative impact of landfills. Both external factors (topography, microclimate conditions, vegetation or type of protective barrier) and internal ones (deposition technology, physical and chemical properties of the waste, or means of protecting the substrate) affect the type and degree of the nuisance, as well as the amount of pollutants coming from a given site (Michałkiewicz, 2009; Adeolu et al., 2011). The aim of the study was to evaluate the variation in cadmium, lead, zinc and copper concentrations in plants growing on the reclaimed Trzebionka zinc and lead post-flotation tailings dump and to analyse factors generating this variation.

\section{Material and methods}

\section{Study location}

The research area was the reclaimed zinc and lead post-flotation tailings dump of the former "ZG Trzebionka S.A" (Fig. 1). Mining Plants, located on the administrative border of the Chrzanów and Trzebinia communes, in the western part of the Małopolska Voivodeship, south of Poland (Klojzy-Kaczmarczyk et al., 2012).
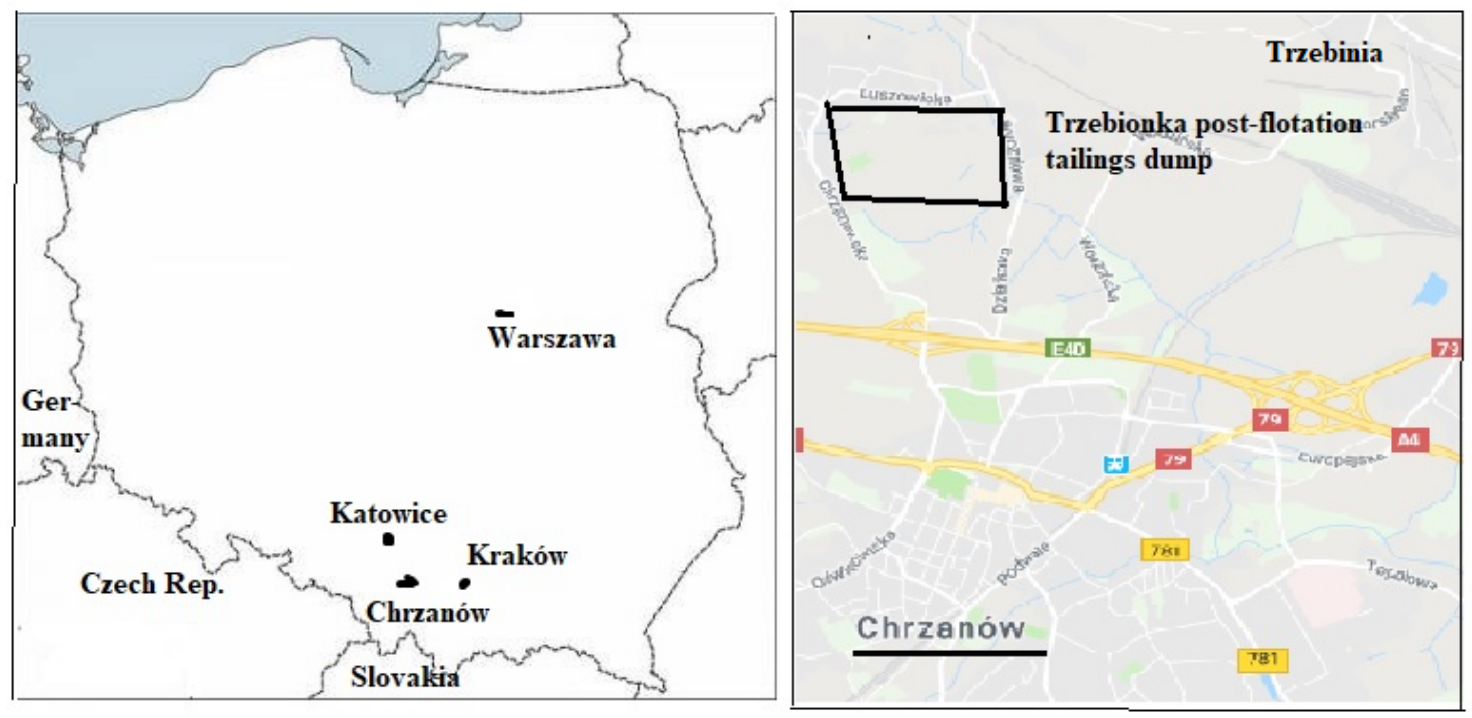

Figure 1. Localisation of research area within the border of Poland (European Union)

The dump, which was established in 1966, is one of the largest ponds collecting tailings from the production of zinc and lead ore concentrates in Poland. It covers an area of about 64 ha and rises about $60 \mathrm{~m}$ above the ground, and the surface of its crown is 20 ha. Waste was transported in the form of an aqueous suspension of finely ground dolomite with zinc and lead carbonates and sulphides with a particle size of less than $0.2 \mathrm{~mm}$. The content of $\mathrm{Zn}$ and $\mathrm{Pb}$ was low $-0.92 \%$ and $0.41 \%$, respectively. The bottom of the pond consists of concentrated and compact sediments whose 
average particle size decreases towards the centre (Klojzy-Kaczmarczyk et al., 2005; Nowak, 2008). During deposition, the coarsest fraction of the tailings was used to build the embankments by means of clay grouting, the finest fraction was used to seal the bottom of the pond, and the rest was placed inside the pond, where the solids underwent sedimentation. The finest waste covered the outermost layer on the crown, and when operation of the landfill was discontinued, the tailings dump underwent reclamation (Neya, 1997; Klojzy-Kaczmarczyk et al., 2009, 2012). The reclamation work consisted in covering the active surface of the dump with latex and creating a sprinkler system (measures to reduce airborne dust), covering the slopes with humus, planting trees and shrubs, sowing grass and legumes, application of stabilized sewage sludge, and pumping water to the irrigation system (the pond was drained prior to reclamation of the top). Vegetation for reclamation was chosen taking into account the difficult conditions (Klojzy-Kaczmarczyk et al., 2009, 2014).

\section{Sampling and analyses}

The research material was obtained by moving about the dump study area from the base of the embankment to the crown and collecting samples in three characteristic research areas (the base of the embankment, the middle of the embankment and the crown of the dump), on the south-west and north-east slopes. Three sampling plots were selected for each research areas. Each sampling plot was an area of about 100 $\mathrm{m}^{2}$, from which we collected five primary samples of the shoots of herbaceous plants and the shoots and leaves of trees - silver birch (Betula pendula Roth), black locust (Robinia pseudoacacia L.), and common rowan (Sorbus aucuparia L.), as well as soil samples. Following homogenization, these samples constituted an average sample of about $1000 \mathrm{~g}$ fresh matter in the case of the plants, and about $500 \mathrm{~g}$ in the case of soil. The aerial parts of the plants were collected using stainless steel secateurs, and the soil samples were collected using a soil sampler from a depth of $0-0.1 \mathrm{~m}$. After air-drying, the plants were ground in a high-speed rotor mill.

The collected soil samples were dried and then sifted through a sieve with a $1 \mathrm{~mm}$ mesh. In soil prepared this way, basic soil properties were determined: $\mathrm{pH}$ in $1 \mathrm{~mol}$ $\mathrm{KCl}$ by the potentiometric method, content of organic carbon using annealing method (Ostrowska et al., 1991). Besides that, total concentrations of cadmium, lead, zinc and copper along with forms of these elements extracted with $1 \mathrm{~mol} \mathrm{dm}^{-3} \mathrm{HCl}$. Dry mineralization was performed using a mixture of concentrated $\mathrm{HNO}_{3}$ and $\mathrm{HClO}_{4}$ for plant material (Ostrowska et al., 1991; Haluschak, 2006). Concentrations of cadmium, lead, zinc and copper were determined by atomic flame absorption spectrometry, using a Unicam Solaar M6 spectrometer. Samples were collected at late summer 2017 year.

The migration conditions of trace elements in the soil-plant system were analysed based on the bioaccumulation factor (BCF) (Nannoni et al., 2016; Li et al., 2007; Marchiol et al., 2013), which illustrates the average ability of plants to accumulate metals from the soil and is calculated as the ratio of the metal concentration in the plant to the metal content of the soil. BCF values greater than 1 indicate high accumulation of metals in the plant, values from 0.1 to 1 indicate moderate accumulation, 0.01 to 0.1 - low accumulation, and below 0.01 - no accumulation (Laskowska and Wiechuła, 2015; Marchiol et al., 2013; Łaszewska et al., 2007). In addition, the coefficient of specific relative accumulation (CSRA Eq. 1) was calculated as the quotient of the concentration of a given element in a given plant and 
the content of this element in other plant species present in the area (Stawinoga et al., 2007).

$$
\operatorname{CSRA}=\frac{c_{r}}{c}\left[^{-}\right]
$$

where:

$\mathrm{c}_{\mathrm{r}}-$ mean quantity of element in the plant

$\mathrm{c}-$ mean quantity of element in all plant species present in the area

The Shapiro-Wilk test showed that the variables did not have normal distribution, so a generalized linear model was used for Poisson distributions to test the relationship between the plant species (black locust, silver birch, rowan and herbaceous plants) and plant part (leaves or shoots) and the location on the landfill (side) and height (base of the embankment, middle or crown). Statistical analyses were performed in Statistica 12.0 software.

\section{Results}

In the present study, cadmium content ranged from $0.14 \mathrm{mg} \cdot \mathrm{kg}^{-1}$ to $4.49 \mathrm{mg} \cdot \mathrm{kg}^{-1}$, with the lowest content in the rowan and successively higher content in the black locust, silver birch and herbaceous plants growing on the crown of dump on the northeast side. In most of the samples, this metal was accumulated mainly in the leaves of the plants (Figure 2a). An exception was the black locust growing on the middle of the embankment on the south-west side, which had higher cadmium content in its shoots, amounting to $1.05 \mathrm{mg} \cdot \mathrm{kg}^{-1}$ (Table 1). The cadmium concentrations were also higher in the shoots of the rowan trees growing on the base and crown of the embankment on the north-east side: $0.63 \mathrm{mg} \cdot \mathrm{kg}^{-1}$ and $0.21 \mathrm{mg} \cdot \mathrm{kg}^{-1}$, respectively (Table 2). Among all the trees, the rowan had the lowest mean cadmium content, similar on all sampling plots, in both the leaves $\left(0.16 \mathrm{mg} \cdot \mathrm{kg}^{-1}-0.54 \mathrm{mg} \cdot \mathrm{kg}^{-1}\right)$ and the shoots $\left(0.18 \mathrm{mg} \cdot \mathrm{kg}^{-1}-0.63 \mathrm{mg} \cdot \mathrm{kg}^{-1}\right)$. In silver birch, irrespective of the sampling location, the cadmium content was similar and higher than in the other trees $(0.91$ $\left.\mathrm{mg} \cdot \mathrm{kg}^{-1}-1.93 \mathrm{mg} \cdot \mathrm{kg}^{-1}\right)$ (Figure 2a). The highest variation in this metal was recorded in the herbaceous plants $-89 \%$, followed by the black locust shoots $-55 \%$, and the lowest in the black locust leaves and silver birch leaves $-3 \%$. The analysis confirms statistically significant variation in the content of this element in the plant species tested (Figures $2 a$ and $3 a(p<0.001)$; Table 3).
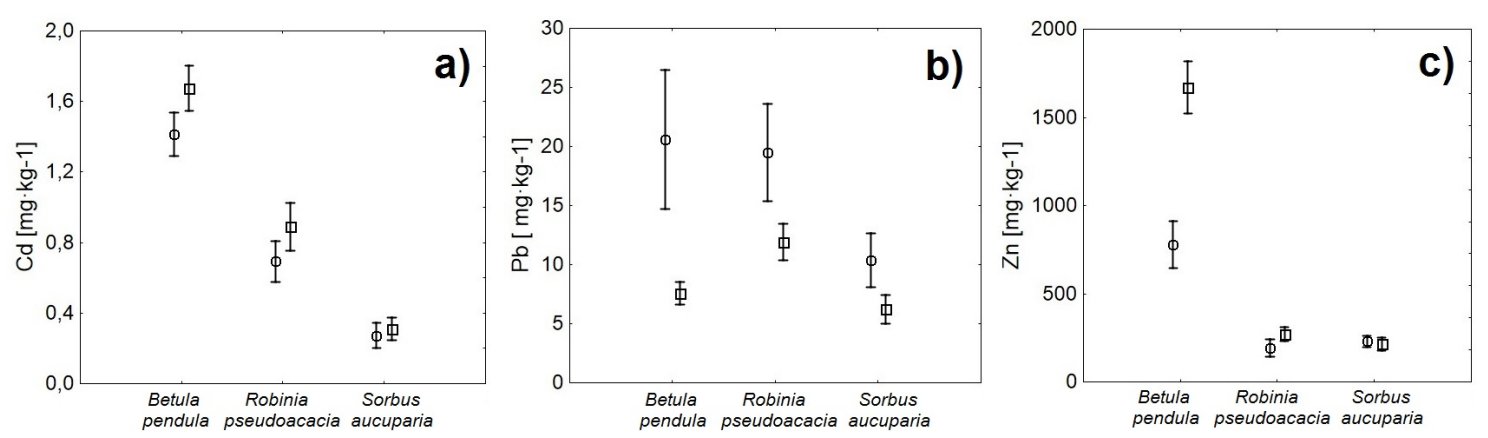

Figure 2. Distribution of mean concentrations of heavy metals in the shoots (circles) and leaves (squares) of three species: silver birch, black locust and common rowan 
Table 1. Mean concentrations of heavy metals in plants and soil for south-west site

\begin{tabular}{|c|c|c|c|c|c|c|c|c|c|c|c|c|}
\hline \multirow[b]{2}{*}{ Site/slope } & \multirow[b]{2}{*}{ Plant } & \multirow[b]{2}{*}{ Organ } & \multicolumn{4}{|c|}{ Content in plants $\mathrm{mg} \cdot \mathrm{kg}^{-1}$} & \multicolumn{4}{|c|}{ Content in soil $\mathbf{m g} \cdot \mathrm{kg}^{-1}$} & \multirow{2}{*}{$\begin{array}{c}\% \\
\text { org } \\
\end{array}$} & \multirow[b]{2}{*}{ pH (KCl) } \\
\hline & & & Cd & $\mathbf{P b}$ & $\mathbf{Z n}$ & $\mathbf{C u}$ & Cd & $\mathbf{P b}$ & Zn & $\mathrm{Cu}$ & & \\
\hline \multirow{7}{*}{ Base } & \multirow{2}{*}{ Betula pendula } & shoot & 1.26 & 27.50 & 1207.40 & 5.79 & \multirow{7}{*}{16.78} & \multirow{7}{*}{645.60} & \multirow{7}{*}{2253.00} & \multirow{7}{*}{78.35} & \multirow{7}{*}{3.20} & \multirow{7}{*}{7.50} \\
\hline & & leaf & 1.45 & 7.40 & 1845.40 & 4.90 & & & & & & \\
\hline & Rohinia nsoudoacacia & shoot & 0.36 & 11.10 & 113.40 & 4.78 & & & & & & \\
\hline & 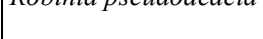 & leaf & 0.62 & 8.30 & 254.60 & 3.46 & & & & & & \\
\hline & \multirow{2}{*}{ Sorbus aucuparia } & shoot & 0.18 & 8.60 & 182.60 & 5.82 & & & & & & \\
\hline & & leaf & 0.18 & 4.10 & 201.80 & 3.93 & & & & & & \\
\hline & Herbaceous plants & shoot & 0.91 & 13.90 & 426.60 & 3.09 & & & & & & \\
\hline \multirow{7}{*}{ Middle } & \multirow{2}{*}{ Betula pendula } & shoot & 0.91 & 17.80 & 1073.90 & 6.18 & \multirow{7}{*}{17.06} & \multirow{7}{*}{621.20} & \multirow{7}{*}{2166.00} & \multirow{7}{*}{72.15} & \multirow{7}{*}{3.00} & \multirow{7}{*}{7.40} \\
\hline & & leaf & 1.12 & 5.30 & 2226.50 & 5.01 & & & & & & \\
\hline & Rohinia nseudoacacio & shoot & 1.05 & 23.30 & 442.90 & 2.91 & & & & & & \\
\hline & 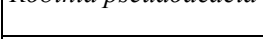 & leaf & 0.65 & 17.50 & 212.20 & 3.79 & & & & & & \\
\hline & \multirow{2}{*}{ Sorbus aucuparia } & shoot & 0.16 & 12.90 & 277.70 & 3.27 & & & & & & \\
\hline & & leaf & 0.31 & 6.20 & 245.30 & 3.15 & & & & & & \\
\hline & Herbaceous plants & shoot & 0.42 & 39.2 & 264.30 & 3.11 & & & & & & \\
\hline \multirow{7}{*}{ Crown } & \multirow{2}{*}{ Betula pendula } & shoot & 1.35 & 10.60 & 427.60 & 4.74 & \multirow{7}{*}{12.56} & \multirow{7}{*}{3415.70} & \multirow{7}{*}{5494.00} & \multirow{7}{*}{93.55} & & \\
\hline & & leaf & 1.88 & 5.60 & 1172.30 & 4.86 & & & & & & \\
\hline & Pohinia ncoudocri & shoot & 0.36 & 8.0 & 96.50 & 5.46 & & & & & & \\
\hline & & leaf & 0.6 & 8.10 & 154.80 & 4.05 & & & & & 4.75 & 7.50 \\
\hline & Sorbus aucunaria & shoot & 0.26 & 5.20 & 176.80 & 6.56 & & & & & & \\
\hline & 然 & leaf & 0.47 & 4.40 & 355.70 & 4.43 & & & & & & \\
\hline & Herbaceous plants & shoot & 4.03 & 16.70 & 292.10 & 4.45 & & & & & & \\
\hline
\end{tabular}

Table 2. Mean concentrations of heavy metals in plants and soil for north-east site

\begin{tabular}{|c|c|c|c|c|c|c|c|c|c|c|c|c|}
\hline \multirow[b]{2}{*}{ Site/slope } & \multirow[b]{2}{*}{ Plant } & \multirow[b]{2}{*}{ Organ } & \multicolumn{4}{|c|}{ Content in plants $\mathrm{mg} \cdot \mathrm{kg}^{-1}$} & \multicolumn{4}{|c|}{ Content in soil $\mathrm{mg} \cdot \mathrm{kg}^{-1}$} & \multirow{2}{*}{$\begin{array}{l}\% \\
\text { org }\end{array}$} & \multirow[b]{2}{*}{ pH (KCl) } \\
\hline & & & Cd & $\mathbf{P b}$ & $\mathbf{Z n}$ & $\mathrm{Cu}$ & Cd & $\mathbf{P b}$ & Zn & $\mathrm{Cu}$ & & \\
\hline \multirow{7}{*}{ base } & \multirow{2}{*}{ Betula pendula } & shoot & 1.74 & 47.70 & 932.40 & 5.20 & \multirow{7}{*}{48.05} & \multirow{7}{*}{1499.50} & \multirow{7}{*}{5592.00} & \multirow{7}{*}{76.45} & \multirow{7}{*}{4.05} & \multirow{7}{*}{7.50} \\
\hline & & leaf & 1.8 & 12.10 & 1808.50 & 3.75 & & & & & & \\
\hline & Pohinia nsoudoasacia & shoot & 0.96 & 32.80 & 184.80 & 4.04 & & & & & & \\
\hline & Kовтпа рsеиаоасаста & leaf & 1.26 & 15.40 & 284.30 & 3.61 & & & & & & \\
\hline & \multirow{2}{*}{ Sorbus aucuparia } & shoot & 0.63 & 13.50 & 383.30 & 4.34 & & & & & & \\
\hline & & leaf & 0.54 & 11.80 & 258.70 & 4.26 & & & & & & \\
\hline & Herbaceous plants & shoot & 1.53 & 3.00 & 145.80 & 5.39 & & & & & & \\
\hline \multirow{7}{*}{ middle } & \multirow{2}{*}{ Betula pendula } & shoot & 1.51 & 10.20 & 529.90 & 3.82 & \multirow{7}{*}{55.27} & \multirow{7}{*}{4414.75} & \multirow{7}{*}{$12,443.50$} & \multirow{7}{*}{407.85} & \multirow{7}{*}{5.75} & \multirow{7}{*}{6.80} \\
\hline & & leaf & 1.87 & 7.80 & 1384.50 & 3.65 & & & & & & \\
\hline & & shoot & 0.71 & 29.40 & 156.90 & 4.87 & & & & & & \\
\hline & Robinıа рsеudoacacıа & leaf & 0.83 & 9.30 & 279.50 & 3.34 & & & & & & \\
\hline & \multirow{2}{*}{ Sorbus aucuparia } & shoot & 0.20 & 18.70 & 181.80 & 4.31 & & & & & & \\
\hline & & leaf & 0.21 & 7.30 & 127.80 & 5.01 & & & & & & \\
\hline & Herbaceous plants & shoot & 1.57 & 15.00 & 290.60 & 5.87 & & & & & & \\
\hline \multirow{7}{*}{ crown } & \multirow{2}{*}{ Betula pendula } & shoot & 1.71 & 9.80 & 495.20 & 4.22 & \multirow{7}{*}{26.03} & \multirow{7}{*}{5101.60} & \multirow{7}{*}{1710.50} & \multirow{7}{*}{375.45} & & \\
\hline & & leaf & 1.93 & 7.20 & 1585.70 & 3.77 & & & & & & \\
\hline & & shoot & 0.72 & 12.30 & 151.90 & 4.39 & & & & & & \\
\hline & Robınıа рsеudoасасıа & leaf & 1.38 & 12.90 & 441.10 & 3.66 & & & & & 5.80 & 7.10 \\
\hline & Sorbus aucunaria & shoot & 0.21 & 3.40 & 176.20 & 4.07 & & & & & & \\
\hline & sorous aucuparta & leaf & 0.16 & 3.60 & 100.70 & 4.41 & & & & & & \\
\hline & Herbaceous plants & shoot & 4.46 & 7.10 & 229.60 & 6.24 & & & & & & \\
\hline
\end{tabular}

org. $=$ content of organic matter 
Table 3. Results of generalized linear model

\begin{tabular}{|c|c|c|c|}
\hline Cd & df & Wald's statistic & $\mathbf{p}$ \\
\hline Residual & 1 & 11.72 & $* *$ \\
\hline Location & 5 & 5.29 & ns \\
\hline Species & 2 & 35.53 & $* * *$ \\
\hline Plant part & 1 & 0.66 & $\mathrm{~ns}$ \\
\hline Location x species & 10 & 4.30 & ns \\
\hline Location $\mathrm{x}$ plant part & 5 & 0.38 & ns \\
\hline Species x plant part & 2 & 0.06 & ns \\
\hline Location $\mathrm{x}$ species $\mathrm{x}$ plant part & 10 & 1.35 & ns \\
\hline $\mathbf{P b}$ & df & Wald's statistic & $\mathbf{p}$ \\
\hline Residual & 1 & 6811.40 & $* * *$ \\
\hline Location & 5 & 187.69 & $* * *$ \\
\hline Species & 2 & 89.35 & $* * *$ \\
\hline Plant part & 1 & 100.03 & $* * *$ \\
\hline Location x species & 10 & 64.46 & $* * *$ \\
\hline Location x plant part & 5 & 21.85 & $* *$ \\
\hline Species x plant part & 2 & 14.40 & $* *$ \\
\hline Location $\mathrm{x}$ species $\mathrm{x}$ plant part & 10 & 38.28 & $* * *$ \\
\hline Zn & df & Wald's statistic & $\mathbf{p}$ \\
\hline Residual & 1 & $1,291,481.39$ & $* * *$ \\
\hline Location & 5 & 1921.66 & $* * *$ \\
\hline Species & 2 & $35,429.32$ & $* * *$ \\
\hline Plant part & 1 & 1383.08 & $* * *$ \\
\hline Location x species & 10 & 1661.00 & $* * *$ \\
\hline Location $\mathrm{x}$ plant part & 5 & 624.25 & $* * *$ \\
\hline Species x plant part & 2 & 1767.54 & $* * *$ \\
\hline Location $\mathrm{x}$ species $\mathrm{x}$ plant part & 10 & 1237.76 & $* * *$ \\
\hline $\mathrm{Cu}$ & df & Wald's statistic & $\mathbf{p}$ \\
\hline Residual & 1 & 1296.97 & $* * *$ \\
\hline Location & 5 & 4.59 & ns \\
\hline Species & 2 & 2.16 & ns \\
\hline Plant part & 1 & 2.88 & ns \\
\hline Location x species & 10 & 7.30 & ns \\
\hline Location x plant part & 5 & 1.50 & ns \\
\hline Species x plant part & 2 & 0.12 & $\mathrm{~ns}$ \\
\hline Location $\mathrm{x}$ species $\mathrm{x}$ plant part & 10 & 3.94 & ns \\
\hline
\end{tabular}

$* \mathrm{p}<0.05, * * \mathrm{p}<0.01, * * * \mathrm{p}<0.001, \mathrm{~ns}=$ not significant

The variation in cadmium concentrations in the plants was associated to a lesser degree with the height gradient (Figure 3a; $p<0.01$ ). No statistically significant 
differences were found in the content of this element in the plant parts or its content in the substrate depending on the research (slope) area where the samples were taken.
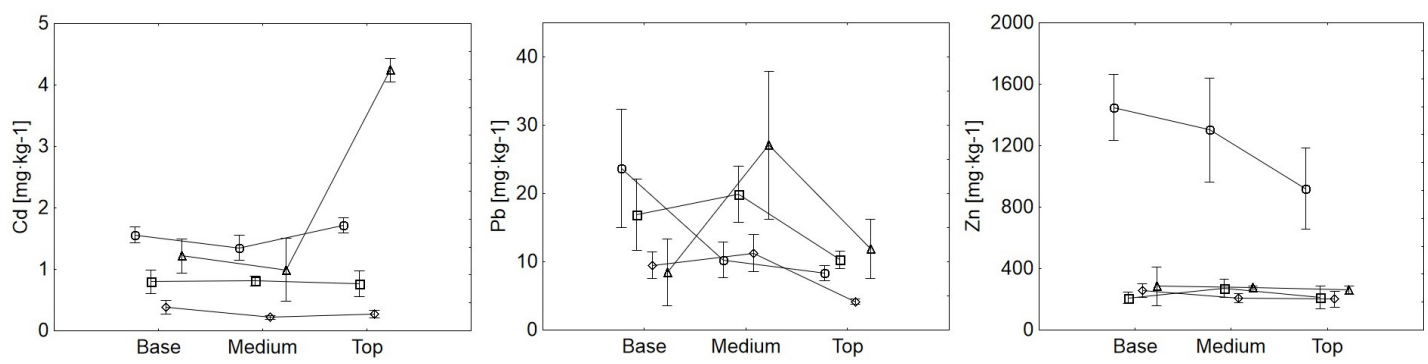

Figure 3. Distribution of mean heavy metal concentrations in the plants: silver birch (circles), black locust (squares), common rowan (diamonds) and herbaceous plants (triangles)

The lead content in the vegetation growing in the study area ranged from $3.0 \mathrm{mg} \cdot \mathrm{kg}^{-1}$ (north-eastern part, base of embankment, herbaceous plants) to $39.5 \mathrm{mg} \cdot \mathrm{kg}^{-1}$ (southwestern part, middle of the embankment, herbaceous plants). The highest coefficient of variation on the south-west slope was found for the herbaceous plants (49\%) and black locust shoots $(47 \%)$, and on the north-east side also for the herbaceous plant samples $(60 \%)$, as well as for the shoots of silver birch (79\%). In most of the samples, on both the south-west and north-east embankments, the shoots accumulated higher lead content. In the case of herbaceous plants, rowan, and black locust, higher lead content was found in the middle of the embankment on the south-west slope than in the other sampling plots. Moreover, as the height increased, the metal content decreased in silver birch (base $>$ middle $>$ crown). On the north-eastern embankment, the concentration of lead in silver birch and black locust decreased in this order: base $>$ middle $>$ crown of embankment. The rowan and herbaceous plants collected from the middle of the embankment had higher content of this metal in comparison with the other sampling plots (the base and crown of the embankment). The analysis confirms a statistically significant relationship between the $\mathrm{Pb}$ concentration and the plant species, plant part, and location on the landfill (both the side of the slope and the height) (Figures $2 b$ and $3 b(p<0.001)$; Table 3). The zinc content on the Trzebionka post-flotation tailings dump ranged from $96.5 \mathrm{mg} \cdot \mathrm{kg}^{-1}$ (south-west side, crown, black locust shoots) to $2226.6 \mathrm{mg} \cdot \mathrm{kg}^{-1}$ (south-west, middle, silver birch leaves). On the southern slope, the highest variability in the content of zinc was observed in the shoots of black locust (73\%). On the northern embankment, the highest variability was recorded for common rowan $(42 \%)$. In the silver birch and black locust trees growing on the north-east embankment, higher concentrations of this element were found in the leaves. The reverse was true in the case of rowan, in which the shoots contained higher amounts of zinc. A similar tendency was noted in most of the samples collected on the south-west slope. The analysis confirmed the statistically significant impact of the sampling location, plant species and plant part on the content of this metal (Figures $2 c$ and $3 c$ $(p<0.001)$; Table 3). Copper content in all plants was similar on individual sampling plots and ranged from $2.91 \mathrm{mg} \cdot \mathrm{kg}^{-1}$ (south-west, middle of embankment, black locust shoots) to $6.58 \mathrm{mg} \cdot \mathrm{kg}^{-1}$ (south-west, crown, rowan shoots). In most of the samples in the study area, this element was stored mainly in the shoots. There was also an increase in the content of this metal in the herbaceous plants along the height transect, from $3.08 \mathrm{mg} \cdot \mathrm{kg}^{-1}$ to $4.48 \mathrm{mg} \cdot \mathrm{kg}^{-1}$ on the south-west embankment and $5.38 \mathrm{mg} \cdot \mathrm{kg}^{-1}$ to 
$6.30 \mathrm{mg} \cdot \mathrm{kg}^{-1}$ on the north-east side. The highest coefficient of variation for the southwest side of the landfill was $27 \%$ for rowan shoots and $25 \%$ for black locust shoots, while for the north-east side of the site it was $13 \%$ for silver birch shoots. This element showed the least variation of all metals analysed. The statistical analysis did not indicate a significant relationship between the plant species, plant part or location on the landfill and the content of this metal (Table 3).

\section{Discussion}

Areas where waste is deposited are usually unfavourable substrates for plant growth, due to the lack of organic matter, unsuitable $\mathrm{pH}$, high concentrations of toxic metals, high salinity, low water retention capacity, low nutrient content, lack of microorganisms, poor physical structure and susceptibility to erosion (Krzaklewski and Pietrzykowski, 2002; Szarek-Łukaszewska and Niklińska, 2002; Wong, 2003; Ye et al., 2002). These properties exert strong selective pressure on colonization by plants, and consequently the waste is often completely devoid of vegetation or exhibits a specific and unique composition of plant species spontaneously appearing there (Woch et al., 2016).

Nadgórska-Socha et al. (2016) tested the efficiency of accumulation of trace elements in black locust leaves. The research was carried out in areas contaminated with heavy metals and the results were compared to uncontaminated areas. The results indicated that this species can grow in metal-contaminated areas and that the contamination affects the physiological parameters of the plant. The average content of elements in the black locust leaves from the Trzebionka dump was $0.89 \mathrm{mg} \cdot \mathrm{kg}^{-1}$ for Cd, $11.92 \mathrm{mg} \cdot \mathrm{kg}^{-1}$ for $\mathrm{Pb}, 271.0 \mathrm{mg} \cdot \mathrm{kg}^{-1}$ for $\mathrm{Zn}$ and $3.65 \mathrm{mg} \cdot \mathrm{kg}^{-1}$ for $\mathrm{Cu}$. In the immediate vicinity of the Miasteczko Śląskie Zinc Smelter, Nadgórska-Socha et al. (2016) reported concentrations of $3.01 \mathrm{mg} \cdot \mathrm{kg}^{-1}$ for $\mathrm{Cd}, 17.69 \mathrm{mg} \cdot \mathrm{kg}^{-1}$ for $\mathrm{Pb}, 109.64 \mathrm{mg} \cdot \mathrm{kg}^{-1}$ for $\mathrm{Zn}$, and $13.11 \mathrm{mg} \cdot \mathrm{kg}^{-1}$ for $\mathrm{Cu}$. As in our research, the levels of $\mathrm{Cd}$ accumulated in the trees were the lowest; $\mathrm{Cu}, \mathrm{Pb}$ and $\mathrm{Zn}$ were accumulated in higher concentrations. $\mathrm{Hu}$ et al. (2014) also assessed the content of heavy metals in various plant species, including black locust, in an industrial region, in a residential area, and by a motorway. The concentrations of elements differed depending on the plant species and on the sampling site. The highest concentrations were recorded near the motorway and in the industrial area. The authors presented the mean content of $\mathrm{Cd}\left(1.10 \mathrm{mg} \cdot \mathrm{kg}^{-1}\right), \mathrm{Pb}\left(4.55 \mathrm{mg} \cdot \mathrm{kg}^{-1}\right)$, $\mathrm{Cu}\left(3.88 \mathrm{mg} \cdot \mathrm{kg}^{-1}\right)$ and $\mathrm{Zn}\left(5.18 \mathrm{mg} \cdot \mathrm{kg}^{-1}\right)$ for black locust. The concentrations for $\mathrm{Pb}$ and $\mathrm{Zn}$ were very different from the results obtained in our study, but are arranged in the same, the most common hierarchy of accumulation: $\mathrm{Cd}<\mathrm{Cu}<\mathrm{Pb}<\mathrm{Zn}$. The results obtained by $\mathrm{Hu}$ et al. (2014) and from the Trzebionka dump indicate that the black locust accumulates lower content of harmful substances than other analysed plant species. Tzvetkova and Petkova (2015) examined black locust leaves in industrial regions of Bulgaria in order to determine the accumulation characteristics of this tree and to evaluate it as a biomonitor of heavy metal pollution. The study was carried out on plantations near the industrial area of Devnya in eastern Bulgaria, which is heavily contaminated by cement plants, nitrogen fertilizers and polyvinyl chloride factories. The leaves of damaged and control plants were tested. The concentrations of heavy metals were higher than those obtained in the Trzebionka tailings dump for lead $\left(30.7 \mathrm{mg} \cdot \mathrm{kg}^{-1}\right)$ and copper $\left(17.2 \mathrm{mg} \cdot \mathrm{kg}^{-1}\right)$; the exception was zinc, with a concentration of $19.0 \mathrm{mg} \cdot \mathrm{kg}^{-}$ ${ }^{1}$. The authors showed that the black locust leaves accumulated $\mathrm{Pb}, \mathrm{Zn}$ and $\mathrm{Cu}$ as the 
concentration of these metals increased in the soil. The average content of heavy metals in the rowan tree leaves (Sorbus aucuparia) was $0.31 \mathrm{mg} \cdot \mathrm{kg}^{-1}$ for Cd, $6.23 \mathrm{mg} \cdot \mathrm{kg}^{-1}$ for $\mathrm{Pb}, 4.20 \mathrm{mg} \cdot \mathrm{kg}^{-1}$ for $\mathrm{Cu}$, and $215.00 \mathrm{mg} \cdot \mathrm{kg}^{-1}$ for $\mathrm{Zn}$, while the concentrations in the shoots were $0.27 \mathrm{mg} \cdot \mathrm{kg}^{-1}$ for $\mathrm{Cd}, 10.38 \mathrm{mg} \cdot \mathrm{kg}^{-1}$ for $\mathrm{Pb}, 4.73 \mathrm{mg} \cdot \mathrm{kg}^{-1}$ for $\mathrm{Cu}$, and $229.7 \mathrm{mg} \cdot \mathrm{kg}^{-1}$ for $\mathrm{Zn}$. In comparison with other trees, this species did not accumulate the highest heavy metal concentrations. Woch et al. (2017), who carried out research on waste heaps left by historical $\mathrm{Zn}-\mathrm{Pb}$ mines, reported that rowan was one of the most common trees in the contaminated area. The authors also state that such areas have diverse species of woody vegetation. Compared with other tree species, silver birch (Betula pendula) shows much greater affinity for zinc, accumulates high concentrations of heavy metals - above the average values given for plants in the literature, and grows rapidly, even in areas with difficult conditions. This is an example of the features necessary in a species suitable for phytoremediation. Research on this species has been carried out by Wisłocka et al. (2006), Margui et al. (2007) and Dmuchowski et al. (2012, 2014). Dmuchowski et al. (2014) conducted work to assess the suitability of silver birch for phytoremediation of zinc contaminated soils. The trees grew on contaminated metallurgical waste heaps and under control conditions. The study showed the potential of this species to accumulate large amounts of zinc in the leaves in both controlled and polluted environments. The authors conclude that silver birch is a species that meets the requirements for plants used for phytoremediation and can be used to clean a zinc contaminated substrate. The analysis showed that in the environment contaminated with zinc, the soil near the trunks of Betula pendula contained much less of the heavy metal than the soil at a distance of $7 \mathrm{~m}$. Dmuchowski et al. (2014) suggested that Betula pendula can be included among zinc hyperaccumulators. Analysis of the results of our research indicates that silver birch has the capacity to store large amounts of zinc $\left(2226.5 \mathrm{mg} \cdot \mathrm{kg}^{-1}\right.$ in leaves collected from the middle of the embankment on the south-west slope). It should be noted here that among all substrate samples, the lowest $\mathrm{Zn}$ content was found in a sample from the middle of the slope on the south-west side of the landfill. Dmuchowski and Sołtykiewicz (2007) reported that the leaves of silver birch contained on average from $300 \mathrm{mg} \cdot \mathrm{kg}^{-1}$ (Białowieża Forest) to $1344 \mathrm{mg} \cdot \mathrm{kg}^{-1}$ of zinc (waste heap of a non-ferrous metal smelter near Olkusz), and in their final conclusion classified the tree as a zinc hyperaccumulator. On the Trzebionka dump, the silver birch leaves accumulated much higher concentrations of this metal (from $1172.3 \mathrm{mg} \cdot \mathrm{kg}^{-1}$ to $2226.5 \mathrm{mg} \cdot \mathrm{kg}^{-1}$ ), thus allowing the species to be counted among hyperaccumulators that can be used in soil phytoremedation processes in areas enriched with trace elements (Krzciuk, 2015). The mean content of zinc in silver birch on the Trzebionka dump was $1670.48 \mathrm{mg} \cdot \mathrm{kg}^{-1}$ in the leaves and $666.63 \mathrm{mg} \cdot \mathrm{kg}^{-1}$ in the shoots, which were the highest values among the plants analysed. Marguí et al. (2007) determined the content of zinc in silver birch in an abandoned lead-zinc mining area in northern Spain. To ensure maximum metal accumulation, the samples were collected in autumn, as in the present study. The concentration of zinc was also high, ranging from 1660 to $3100 \mathrm{mg} \cdot \mathrm{kg}^{-1}$, while the sample from the control area contained $225 \mathrm{mg} \cdot \mathrm{kg}^{-1} \mathrm{Zn}$. Chaabani et al. (2017) conducted research on the content of $\mathrm{Pb}, \mathrm{Zn}$ and $\mathrm{Cd}$ in various species of herbaceous plants found on the site of former zinc and lead ore mines in northern Tunisia. The concentrations of these elements reported in the aerial parts of the plants were in the following ranges: $\mathrm{Cd} \quad 0.3-886 \mathrm{mg} \cdot \mathrm{kg}^{-1}, \mathrm{~Pb} \quad 2.2-341 \mathrm{mg} \cdot \mathrm{kg}^{-1}$, and $\mathrm{Zn} 30.1-$ $1048.5 \mathrm{mg} \cdot \mathrm{kg}^{-1}$. The maximum concentrations of cadmium and lead are many times 
higher than those found in our study. However, it should be noted that the soils in those locations also have extremely high concentrations of these elements. Wójcik et al. (2014) analysed the content of heavy metals in the shoots of 38 species of herbaceous plants found on mining and metallurgical waste landfills. Zinc in the shoots of the plants ranged from 59.24 to $901.5 \mathrm{mg} \cdot \mathrm{kg}^{-1}$, lead from $3.23 \mathrm{mg} \cdot \mathrm{kg}^{-1}$ to $116.92 \mathrm{mg} \cdot \mathrm{kg}^{-1}$, and cadmium from $0.54 \mathrm{mg} \cdot \mathrm{kg}^{-1}$ to $26.86 \mathrm{mg} \cdot \mathrm{kg}^{-1}$. In this case as well, the maximum concentrations of these elements were significantly higher than in our research. Bech et al. (2012) report the following average concentrations for the stems of herbaceous plants growing on the site of an antimony mine in the eastern Pyrenees: for $\mathrm{Pb} 3.3-$ $289 \mathrm{mg} \cdot \mathrm{kg}^{-1}, \mathrm{Zn} 17-81 \mathrm{mg} \cdot \mathrm{kg}^{-1}, \mathrm{Cu} 12-36 \mathrm{mg} \cdot \mathrm{kg}^{-1}$, and $\mathrm{Cd}<0.1-0.2 \mathrm{mg} \cdot \mathrm{kg}^{-1}$. One of the factors influencing the accumulation of heavy metals in plants is their species. Calculations of coefficients such as the enrichment factor and translocation factor are used to obtain information on the suitability of plants for removing metals from contaminated soil. Plant testing can be used in remediation of contaminated soils, e.g. by lead and zinc. In addition, among a set of analysed species we can choose the ones that are suitable for reclamation and those that are candidates for stabilization of metals in the soil and for soil protection (Kirat and Aydin, 2015; Zhao and Duo, 2015). Zhao and Duo (2015) draw attention to the risk of heavy metals returning to the environment in the phytoextraction process. According to the authors, shoots of plants with accumulated harmful substances should undergo appropriate recovery and treatment. Neither the herbaceous plants nor the trees included in the study accumulated $\mathrm{Cd}, \mathrm{Pb}$, $\mathrm{Zn}$ and $\mathrm{Cu}$ intensively $(\mathrm{BCF}<1)$. The silver birch and herbaceous plants had a moderate biological concentration factor $(0.1 \leq \mathrm{BCF} \leq 1.0)$ for $\mathrm{Cd}$ and $\mathrm{Zn}$. Black locust and rowan growing on the middle of embankment and on crown of the on the southwest side had moderate zinc biological concentration factor. Regarding lead content, it should be noted that the herbaceous plants on the south-west embankment of the landfill had a low level of bioaccumulation of this metal $(0.01 \leq \mathrm{BCF} \leq 0.06)$. Bioaccumulation of this element was also low in the silver birch $(0.01 \leq \mathrm{BCF} \leq 0.03)$ and black locust $(0.01<\mathrm{BCF}<0.02)$ growing at the base and middle of the embankment on the same side. On the north-east side, weak accumulation of lead $(\mathrm{BCF}=0.02)$ was found in a couple of samples of silver birch and black locust growing at the base of the embankment, but no accumulation of this metal $(B C F \leq 0.01)$ was noted in the remaining plants. Regarding copper content, accumulation of this element was weak in all tested plants growing on the southern side of the embankment: herbaceous plants $(0.03 \leq \mathrm{BCF} \leq 0.06)$, silver birch $(0.05 \leq \mathrm{BCF} \leq 0.08)$, black locust $(0.04 \leq \mathrm{BCF} \leq 0.07)$ and common rowan $(0.03 \leq \mathrm{BCF} \leq 0.08)$. On the north side, copper accumulation was weak in herbaceous plants growing in the middle of the embankment and on the crown $(\mathrm{BCF}=0.02)$.

Higher mean values for the biological concentration factor were found in plants growing on the south-west slope of the dump. Of the elements analysed, zinc and cadmium were accumulated in greater quantities than lead and copper. Comparison of $\mathrm{BCF}$ valuesbetween plants reveals that the silver birch trees and herbaceous plants had higher average values for this factor than the black locust and rowan (Table 4). To determine the selective metal accumulation capacity, the coefficient of specific relative accumulation (CSRA) was calculated. This coefficient can be used to categorize plant species according to their ability to accumulate individual elements (Laszewska et al., 2007; Parzych et al., 2016). Furthermore, calculation of this coefficient enables a more complete illustration of the problem of metal accumulation, as it provides information 
relating to other plants growing in a given area (Stawinoga et al., 2007). Comparison of the CSRA coefficients for the plant species included in the study shows that silver birch had the highest zinc accumulation capacity (CSRA $=2.39$ and 2.33), while the herbaceous plants had the highest capacity to accumulate cadmium (CSRA $=2.02$ and 2.04). In the case of lead, the greatest storage capacity was found for the herbaceous plants on the southern slope $(\mathrm{CSRA}=1.87)$ and for black locust $(\mathrm{CSRA}=1.80)$ and silver birch $(\mathrm{CSRA}=1.63)$ on the north-east slope. In the case of copper, the CSRA values were similar (0.80-1.33). It can also be seen that the rowan trees had the lowest capacity to accumulate $\mathrm{Cd}, \mathrm{Pb}, \mathrm{Zn}$ and $\mathrm{Cu}$.

Table 4. Comparison of mean BCF values on the northern and southern embankments of the dump

\begin{tabular}{c|c|c|c|c|c|c|c|c}
\hline & \multicolumn{2}{|c|}{ Cd } & \multicolumn{2}{c|}{ Zn } & \multicolumn{2}{c|}{ Pb } & \multicolumn{2}{c}{ Cu } \\
\cline { 2 - 9 } & SW & NE & SW & NE & SW & NE & SW & NE \\
\hline Betula pendula & 0.09 & 0.05 & 0.48 & 0.13 & 0.01 & 0.01 & 0.07 & 0.02 \\
\hline Robinia pseudoacacia & 0.04 & 0.03 & 0.08 & 0.03 & 0.01 & 0.01 & 0.05 & 0.02 \\
\hline Sorbus aucuparia & 0.02 & 0.01 & 0.09 & 0.02 & 0.01 & 0.00 & 0.06 & 0.03 \\
\hline Herbaceous plants & 0.12 & 0.06 & 0.12 & 0.03 & 0.03 & 0.00 & 0.04 & 0.04 \\
\hline
\end{tabular}

\section{Conclusions}

The variation in accumulation of the investigated metals between the analysed plant species, plant parts, and locations on the landfill is particularly evident in the case of lead and zinc. These features are less significant in the case of the distribution of cadmium and copper concentrations. Neither the herbaceous plants nor the trees included in the study showed intensive accumulation of the metals tested $(\mathrm{BCF}<1)$. Higher mean values for the bioaccumulation factor were found for plants growing on the south-west slope of the post-flotation tailings dump. Among the species analysed, rowan (Sorbus aucuparia) accumulated smaller amounts of metals than the other plants, while silver birch (Betula pendula) showed the capacity for hyperaccumulation of zinc, which confirms that it is a suitable species for reclamation processes.

Acknowledgements. The research was carried on under financial support from DS-3337/KEKiOP/2017.

\section{REFERENCES}

[1] Adeolu A., Ada O., Gbenga, A., Adebayo, O. (2011): Assessment of groundwater contamination by leachate near a municipal solid waste landfill. - African Journal of Environmental Science and Technology 5(11): 933-940.

[2] Alloway, B. J. (2013): Sources of Heavy Metals and Metalloids in Soils. - In: Alloway, B. J. (Ed.), Heavy Metals in Soils. Trace Metals and Metalloids in Soils and Their Bioavailability. Springer Science \& Business Media, Dordrecht, pp. 11-50.

[3] Bech, J., Corrales, I., Tume, P., Barcelo, J., Duran, P., Roca, N., Poschenrieder, C. (2012): Accumulation of antimony and other potentially toxic elements in plants around a former antimony mine located in the Ribes Valley (Eastern Pyrenees). - Journal of Geochemical Explorations 113: 100-105. 
[4] Chaabani, S., Abdelmalek-Babbou, C., Ben Ahmed, H., Chaabani, A., Sebei, A. (2017): Phytoremediation assessment of native plants growing on $\mathrm{Pb}-\mathrm{Zn}$ mine site Northern Tunisia. - Environmental Earth Sciences 76: 584.

[5] Dmuchowski, W., Sołtykiewicz, E. (2007): Hiperakumulacja cynku w liściach brzozy brodawkowatej (Betula pendula Roth). - Ochrona środowiska i zasobów naturalnych 31 : 209-214.

[6] Dmuchowski, W., Baczewska, A. H., Gozdowski, D. (2012): Silver Birch (Betula pendula Roth) as Zinc Hyperaccumulator. - In: Nriagu, J., Pacyna, J., Szefer, P., Markert, B., Wuenschmann, S., Namiesnik, J. (eds.) Heavy Metals in the Environment. Maralte BV, Voorschoten, The Netherlands, pp. 19-5.

[7] Dmuchowski, W., Gozdowski, D., Brągoszewska, P., Baczewska, A. H., Suwara, I. (2014): Phytoremediation of zinc contaminated soils using silver birch (Betula pendula Roth). - Ecological Engineering 71: 32-35.

[8] European Statistical Office (Eurostat) (2017): Energy, transport and environment indicators. - http://ec.europa.eu/eurostat/documents/3217494/8435375/KS-DK-17-001EN-N.pdf/18d1 ecfd-acd8-4390-ade6-e1 f858d746da.

[9] Grattan, J., Huxley, S., Pyatt, F. (2003): Modern Bedouin exposures to copper contamination: An imperial legacy? - Ecotoxicology and Environmental Safety 55(1): 108-115.

[10] Haluschak, P. (2006): Laboratory Methods of Soil Analysis. - Canada-Manitoba Soil Survey. $\quad \mathrm{http}: / /$ manitoba.ca/agriculture/land/soil-survey/pubs/laboratory_methods of_soil_analysis.pdf.

[11] Hu, Y., Wang, D., Wei, L., Zhang, X., Song, B. (2014): Bioaccumulation of heavy metals in plant leaves from Yan'an City of the Loess Plateau, China. - Ecotoxicology and Environmental Safety 110: 82-88.

[12] Janas, M., Zawadzka, A. (2017): Wpływ składowiska odpadów przemysłowych na środowisko The impact of industrial waste landfill on the environment. - Ecological Engineering 18(3): 64-73.

[13] Kirat, G., Aydin, N. (2015): Pb-Zn accumulation in plants grown in and around a Pb-Zn mine. - Polish Journal of Environmental Studies 24(2): 545-554.

[14] Klojzy-Kaczmarczyk, B., Makoudi, S., Kucharska, A., Mazurek, J., Żółtek, J. (2005): Program Ochrony Środowiska dla Powiatu Chrzanowskiego. - IGSMiE PAN, Chrzanów. http://bip.malopolska.pl/pobierz/307372.html.

[15] Klojzy-Kaczmarczyk, B., Mazurek, J., Chobot, C., Makoudi, S., Żółtek, J., Kurek, T. (2009): Dokumentacja określająca techniczny sposób zamknięcia i rekultywacji składowiska odpadów poflotacyjnych (stawu osadowego) ZG Trzebionka S.A. W likwidacji. - IGSMiE PAN, Kraków.

[16] Klojzy-Kaczmarczyk, B., Kurek, T., Mazurek, J. (2012): Emisja zanieczyszczeń pyłowych na etapie eksploatacji oraz zamykania składowiska odpadów poflotacyjnych kopalni rudy Zn-Pb „Trzebionka”. - Rocznik Ochrony Środowiska 14: 844-855.

[17] Klojzy-Kaczmarczyk, B., Makoudi, S., Mazurek, J., Staszczak, J., Żółtek, J. (2014): Aktualizacja Programu Ochrony Środowiska dla Gminy Trzebinia na lata 2014-2017 z uwzględnieniem perspektywy na lata 2018-2021. - IGSMiE PAN, Trzebinia. https://bip.malopolska.pl/e,pobierz,get.html?id=1097288.

[18] Koolivand, A., Mazandaranizadeh, H., Binavapoor, M., Mohammadtaheri, A., Saeedi, R. (2017): Hazardous and industrial waste composition and associated management activities in Caspian Industrial Park, Iran. - Environmental Nanotechnology, Monitoring and Management 7: 9-14.

[19] Krzaklewski, W., Pietrzykowski, M. (2002): Selected physico-chemical properties of zinc and lead ore tailings and their biological stabilisation. - Water, Air, and Soil Pollution 141(1-4): 125-141.

[20] Krzciuk, K. (2015): Hiperakumulatory roślinne, charakterystyka, badania i znaczenie praktyczne. - Kosmos, Problemy Nauk Biologicznych 64(2): 293-304. 
[21] Laskowska, A., Wiechuła, D. (2015): Accumulation of lead and zinc in chosen medicinal plants from Katowice recreation area. - Environmental Protection and Natural Resources 26(63): 11-15.

[22] Łaszewska, A., Kowol, J., Wiechuła, D., Kwapuliński, J. (2007): Kumulacja metali w wybranych gatunkach roślin leczniczych z terenu Beskidu Śląskiego i Beskidu Żywieckiego. - Problemy Ekologii 11(6): 285-29.

[23] Li, M., Luo, Y., Su, Z. (2007): Heavy metal concentrations in soils and plant accumulation in a restored manganese mine land in Guangxi, South China. Environmental Pollution 147: 168-175.

[24] Marchiol, L., Fellet, G., Boscutti, F., Montella, C., Mozzi, R., Guarino, C. (2013): Gentle remediation at the former "Pertusola Sud" Zinc Smelter: Evaluation of native species for phytoremediation purposes. - Ecological Engineering 53: 343-353.

[25] Margu1, E., Queralt, I., Carvalho, M. L., Hidalgo, M. (2007): Assessment of metal availability to vegetation (Betula pendula) in $\mathrm{Pb}-\mathrm{Zn}$ ore concentrate residues with different features. - Environmental Pollution 145: 179-184.

[26] Michałkiewicz, M. (2009): Składowiska odpadów jako źródła skażenia mikrobiologicznego. Budowa i eksploatacja bezpiecznych składowisk odpadów. Gdynia, Wydawnictwo Abrys.

[27] Nadgórska-Socha, A., Kandziora-Ciupa, M., Ciepal, R., Barczyk, G. (2016): Robinia pseudoacacia and Melandrium album in trace elements biomonitoring and air pollution tolerance index study. - International Journal of Environmental Science and Technology 13: 1741-1752.

[28] Nannoni, F., Rossi, S., Protano, G. (2016): Potentially toxic element contamination in soil and accumulation in maize plants in a smelter area in Kosovo. - Environmental Science and Pollution Research 23: 11937-11946.

[29] Neya, R. (1997): Surowce mineralne Polski. - Wydawnictwo Centrum PPGSMiE PAN, Kraków.

[30] Nowak, A. (2008): Ekologiczno-techniczne aspekty procesów pozyskiwania koncentratów cynku i ołowiu. - Praca doktorska, Politechnika Krakowska. http://suw.biblos.pk.edu.pl/downloadResource\&mId=162478.

[31] Ostrowska, A., Gawliński, S., Zczubiałka, Z. (1991): Metody analiz i oceny właściwości gleb i roślin, katalog. - Wydawnictwo IOŚ, Warszawa.

[32] Parzych, A., Cymer, M., Macheta, K. (2016): Leaves and roots of Typha latifolia L. and Iris pseudacorus L. as bioindicators of contamination of bottom sediments by heavy metals. - Limnological Review 16(2): 77-83.

[33] Polish Central Statistical Office (PCSO) (2017): Environment. https://stat.gov.pl/download/gfx/portalinformacyjny/pl/defaultaktualnosci/5484/1/18/1/oc hrona_srodowiska_2017.pdf.

[34] Pyatt, F., Gilmore, G., Grattan, J., Hunt, C., Mclaren, S. (2000): An imperial legacy? An exploration of the environmental impact of ancient metal mining and smelting in southern Jordan. - Journal of Archaeological Science 27(9): 771-778.

[35] Pyatt, F., Pyatt, A., Walker, C., Sheen, T., Grattan, J. (2005): The heavy metal content of skeletons from an ancient metalliferous polluted area in southern Jordan with particular reference to bioaccumulation and human health. - Ecotoxicology and Environmental Safety 60: 295-300.

[36] Salihoglu, G. (2010): Industrial hazardous waste management in Turkey. Current state of the field and primary challenges. - Journal of Hazardous Materials 177: 42-56.

[37] Stawinoga, D., Kowol, J., Bogunia, M., Drużba, D., Urban, A., Librowska, H. (2007): Metody ustalania rzeczywistej intoksykacji roślin leczniczych metalami toksycznymi. Farmceutyczny Przegląd Naukaukowy 10: 27-30.

[38] Stefanowicz, A., Woch, M., Kapusta, P. (2014): Inconspicuous waste heaps left by historical $\mathrm{Zn}-\mathrm{Pb}$ mining are hot spots of soil contamination. - Geoderma 1-8: 235-236. 
[39] Szarek-Łukaszewska, G., Niklińska, M. (2002): Concentration of alkaline and heavy metals in Biscutella laevigata L. and Plantago lanceolata L. Growing on calamine spoils (S. Poland). - Acta Biologica Cracoviensia Series Botanica 44(January): 29-38.

[40] Teršič T., Gosar M., Šajn R. (2009): Impact of mining activities on soils and sediments at the historical mining area in Podljubelj, NW Slovenia. - Journal of Geochemical Exploration 100(1): 1-10.

[41] Tordoff G., Baker A., Willis A. (2000): Current approaches to the revegetation and reclamation of metalliferous mine wastes. - Chemosphere 41: 219-228.

[42] Tzvetkova N., Petkova K. (2015): Bioaccumulation of heavy metals by the leaves of Robinia pseudoacacia as a bioindicator tree in industrial zones. - Journal of Environmental Biolgy 36: 59-63.

[43] Wisłocka M., Krawczyk J., Klink A., Morrison L. (2006): Bioaccumulation of heavy metals by selected plant species from uranium mining dumps in the Sudety Mts., Poland. - Polish Journal of Environmental Studies 15(5): 811-819.

[44] Woch M., Kapusta P., Stefanowicz, A. (2016): Variation in dry grassland communities along a heavy metals gradient. - Ecotoxicology 25(1): 80-90.

[45] Woch M., Stefanowicz A., Stanek M. (2017): Waste heaps left by historical Zn-Pb ore mining are hotspots of species diversity of beech forest understory vegetation. - Science of the Total Environment 599-600: 32-41.

[46] Wójcik M., Sugier P., Siebielec G. (2014): Metal accumulation strategies in plants spontaneously inhabiting $\mathrm{Zn}-\mathrm{Pb}$ waste deposits. - Science of the Total Environment 487: 313-322.

[47] Wong M. (2003): Ecological restoration of mine degraded soils, with emphasis on metal contaminated soils. - Chemosphere 50: 775-780.

[48] Ye Z., Shu W., Zhang Z., Lan C., Wong, M. (2002): Evaluation of major constraints to revegetation of lead/zinc mine tailings using bioassay techniques. - Chemosphere 47(10): 1103-11.

[49] Zhao S., Duo L. (2015): Bioaccumulation of cadmium, copper, zinc, and nickel by weed species from municipal solid waste compost. - Polish Journal of Environmental Studies 24(1): 413-417. 